\title{
Physiological response and performance of tambaqui fed with diets supplemented with Amazonian nut
}

\author{
Respostas fisiológicas e desempenho do tambaqui alimentado com dietas suplementadas \\ com castanha da Amazônia
}

\author{
Marcio Quara de Carvalho Santos ${ }^{\mathrm{I}}$ César Augusto Oishi ${ }^{\mathrm{I}}$ Manoel Pereira Filho ${ }^{\mathrm{I}}$ \\ Mariana do Amaral Camara Lima ${ }^{I}$ Eduardo Akifumi Ono ${ }^{I}$ Elizabeth Gusmão Affonso $^{{ }^{*}}$
}

\begin{abstract}
The present study evaluated the effectiveness of Amazonian nut (Bertholletia excelsa) as an alternative source of vegetal protein in tambaqui (Colossoma macropomum) diet. Performance and physiological status of fish fed for 60 days were evaluated. Four experimental isonitrogenous diets with $36 \%$ crude protein were formulated with increasing levels of nut meal $(0,10,20$ and 30\%). Results showed the same growth performance for fish fed with diet with different levels of Amazonian nut than that without this ingredient (control). Analysis of physiological parameters (hematocrit, erythrocyte number, hemoglobin concentration, hematimetric indexes, total plasma protein and plasma glucose) corroborate these results, with no significant differences among treatments. Therefore, adding up to $30 \%$ of Amazonian nut in tambaqui diet there is no negative effect on physiological homeostasis and growth performance, indicating that the Amazonian nut is a promising alternative dietary protein source ingredient for tambaqui.
\end{abstract}

Key words: Bertholletia excelsa, Colossoma macropomum, physiological stress, regional ingredient, nutrition, fish farming

\section{RESUMO}

Este estudo avaliou a eficácia da farinha de castanha da Amazônia (Bertholletia excelsa) como fonte alternativa de proteína vegetal na dieta do tambaqui (Colossoma macropomum). Para isso, foram avaliados o desempenho e o estado fisiológico dos peixes alimentados durante 60 dias. Foram formuladas quatro dietas experimentais isoproteicas com $36 \%$ proteína bruta, com níveis crescentes de farinha de castanha $(0,10,20$ e 30\%). Os resultados mostraram que os diferentes níveis de castanha da Amazônia mantiveram o mesmo desempenho zootécnico obtido para os peixes alimentados com dieta sem esse ingrediente (controle). Esses resultados são corroborados pela análise dos parâmetros fisiológicos: hematócrito, número de eritrócitos, concentração de hemoglobina, índices hematimétricos, proteínas plasmáticas totais e glicose plasmática, os quais não demonstraram diferenças significativas relacionadas aos diferentes tratamentos. Portanto, até $30 \%$ de farinha de castanha da Amazônia pode ser adicionada à ração sem comprometer a homeostase fisiológica e o desempenho do tambaqui, mostrando-se como um promissor ingrediente alternativo de fonte proteica na dieta para essa espécie.

Palavras-chave: Bertholletia excelsa, Colossoma macropomum, estresse fisiológico, ingrediente regional, nutrição, piscicultura.

\section{INTRODUCTION}

Tambaqui (Colossoma macropomum) is a species native from the Amazon basin whose cultivation is increasing in all tropical regions of Brazil due to its performance under culturing condition and is also relatively easy to manage, presenting fast growth, high productivity and elevated consumer acceptability (ROUBACHet al., 2003).

The production of cultured fish in the Amazonas State was 8,927MT in 2007 (IBAMA, 2007), $75 \%$ of which, approximately, corresponded to tambaqui production, amount insufficient to supply the Manaus market. The high feed cost in Amazonas has inhibited investors and results in dependency of inputs brought from other regions (ONO, 2005). Fish meal is among the main used ingredients but is becoming increasingly

'Coordenação de Pesquisas em Aquicultura (CPAQ), Instituto Nacional de Pesquisas da Amazônia (INPA). Av. André Araújo, 2936, Aleixo, CP 478, 69060-001, Manaus, AM, Brasil. E-mail: pgusmao@inpa.gov.br. *Autor para correspondência. 
scarce and, consequently, expensive worldwide (TACON et al., 2006). As a result, several studies have been carried out aiming to replace this ingredient by another protein sources, such as soybean meal (SALZE et al., 2010).

Currently, researches are trying to replace traditional ingredients by ingredients from the Amazon region in the feed formulation, in order to reduce cost and dependency of external supply. Examples are the results described by PEREIRA JR. (2006) that partially replaced (21\%) fish meal protein by leucena leaf meal (Leucaena leucocephala) in ration for tambaqui juveniles. SILVA et al. (2003) substituted 55\% of maize by fruits (jauari, Astrocaryum jauari and embaúba, Cecropia sp.) and regional seeds meal (munguba, Pseudobombax munguba and seringa barriguda, Hevea spruceana) in tambaqui feed. OLIVEIRA (2005) replaced $50 \%$ of commercial feed by fruits (catoré Crataeva benthami, jauari, embaúba and camu-camu Myrciaria dubia) and seed (munguba) for juvenile tambaqui.

Among the great variety of natural nutrients originated from the Amazon region, there is the Amazonian nut seed (Bertholletia excelsa, H.B.K.), previously named Brazilian nut or Pará nut. Due to its high value, the quality requirement of the international market and the low consumption in the domestic market, a large amount of the nut produced is discarded because of defects in the nuts which imply losses in agroindustry and extrativist cooperatives in the region. The Amazonian nut presents high energy value and is rich in high biological value proteins, being a healthful ingredient characterized as an important antioxidant and immunostimulant (SOUZA \& MENEZES, 2004). Therefore, the residues from agro-industry and cooperatives are a potential alternative ingredient for fish feed.

Although growth performance parameters are the most commonly used in evaluating the efficiency of nutrition components in fish feeds, currently the evaluation of physiological status of fish has been an important source of information in these studies and, certainly, represents a great contribution for the success of the intensive aquatic production systems (ANDRADE et al., 2007).

Thus, in order to contribute to the studies on the Amazon cultured fish species, especially tambaqui, the present research evaluated the physiological status and performance of this species fed with Amazonian nut residue as alternative feed ingredient.

\section{MATERIAL AND METHODS}

Tambaqui with approximately $0.5 \mathrm{~g}$ were obtained in a fish farming located in Rio Preto da Eva/ $\mathrm{AM}$ and transported to CPAQ/INPA (Aquaculture Research Coordination) where they were acclimated and fed with commercial feed containing $40 \%$ crude protein four times a day for a 60 -day period.

Two hundred and forty fish $(29.0 \pm 2.7 \mathrm{~g})$ were distributed in twelve 200-L tanks with continuous aeration and $10 \%$ daily water exchange and submitted to four treatments in triplicates: $\mathrm{AO}$ (control), A10, A20 and A30, corresponding to $0,10,20$ and $30 \%$ of Amazonian nut meal addition to the diets. The Amazonian nut residue was obtained from the Amazon Nut Producers Association and Agroextrativist Cooperative in the municipalities of Xapuri, Epitaciolândia and Brasiléia, in the State of Acre, at a cost of $\mathrm{R} \$ 0.20 \mathrm{~kg}^{-1}$. Four pelletized isonitrogenous diets containing $36 \%$ crude protein were formulated, with increasing levels of Amazonian nut meal according to table 1.

Fish were fed twice a day until apparent satiation, during a 60-day period. All fish were weighted monthly. For blood parameter analysis, blood samples were collected from ten fish in the beginning of the experiments and from six fish of each experimental unit at 60 days.

Fish were anesthetized with 100ppm benzocaine before blood extraction, and samples were drawn through caudal punction using syringe containing 10\% EDTA and used for the following analyses: hematocrit (Ht), by the microhematocrit method using heparinized capillary tubes; erythrocyte counting (RBC) in a Neubauer chamber; hemoglobin $(\mathrm{Hb})$, total plasma protein (TPP) and plasma glucose (Gl) concentration were determined by using specific commercial kits (Doles, GO). The hematimetric indexes mean corpuscular volume (MCV) and mean corpuscular hemoglobin concentration (MCHC) were calculated from the $\mathrm{RBC}, \mathrm{Ht}$ and $\mathrm{Hb}$ of each individual.

Before and during all the experimental period, physical and chemical water parameters of bioassay tanks were analyzed. Dissolved oxygen, temperature, electrical conductivity and $\mathrm{pH}$ were measured through multiparameter digital analyzer (Yellow Springs Instruments - YSI). Total ammonia and nitrite concentrations were determined by spectrophotometric methods according to VERDOUW et al. (1978) and BOYD \& TUCKER (1992), respectively.

Results from treatments and water quality were evaluated by analysis of variance (ANOVA). 
Table 1 - Experimental diet composition and cost with increasing levels of Amazonian nut meal fed to tambaqui juveniles. A0 (control); A10; A20; A30 with 0, 10, 20 and 30\% Amazonian nut meal, respectively.

\begin{tabular}{|c|c|c|c|c|}
\hline \multirow{2}{*}{ Ingredients (\%) } & \multicolumn{4}{|c|}{------------Experimental diets------------ } \\
\hline & A0 & A 10 & A 20 & $\mathrm{~A} 30$ \\
\hline Fish meal & 10.0 & 7.5 & 6.5 & 5.5 \\
\hline Soybean meal & 37.0 & 36.5 & 35.0 & 34.5 \\
\hline Corn meal & 10.0 & 8.0 & 6.0 & 3.0 \\
\hline Wheat meal & 22.0 & 17.0 & 12.0 & 5.0 \\
\hline Amazonian nut meal & 0.0 & 10.0 & 20.0 & 30.0 \\
\hline $\begin{array}{l}\text { Vitamin and mineral } \\
\text { suplement }\end{array}$ & 1.0 & 1.0 & 1.0 & 1.0 \\
\hline Corn gluten meal & 15.0 & 15.0 & 15.0 & 15.0 \\
\hline Soybean oil & 5.0 & 5.0 & 4.5 & 6.0 \\
\hline Total & 100.0 & 100.0 & 100.0 & 100.0 \\
\hline Crude protein $(\%)$ & 36.6 & 36.1 & 36.0 & 36.0 \\
\hline $\begin{array}{l}\text { Gross energy } \\
\left(\mathrm{kcal} \mathrm{kg}^{-1}\right)^{2}\end{array}$ & 3983.0 & 3828.0 & 3654.0 & 3603.0 \\
\hline $\begin{array}{l}\text { Gross energy/Crude } \\
\text { protein ratio }\end{array}$ & 108.8 & 106.0 & 101.5 & 100.1 \\
\hline $\begin{array}{l}\text { Cost of ingredients } \\
\left(\mathrm{R} \$ \mathrm{~kg}^{-1}\right)\end{array}$ & 1.24 & 1.18 & 1.13 & 1.12 \\
\hline
\end{tabular}

${ }^{1}$ Composition per kg of product: Folic acid 250mg; Pantotenic acid 5000mg; Biotin 125mg; Cobalt 25mg; Copper 2000mg; Iron $13820 \mathrm{mg}$; Iodine 100mg; Manganese 3750mg; Niacin 5000mg; Sellenium 75mg; Zinc $874,95 \mathrm{mg}$; vit. A 1000000 UI, vit. B1 $1250 \mathrm{mg}$, vit. B12 3750mg, vit. B2 2500mg, vit. B6 2485mg, vit. C $28000 \mathrm{mg}$; vit. D3 500000UI; vit. E 20000 UI; vit. K3 500mg.

${ }^{2}$ Gross energy calculated based on energy values for crude proteins = $5.64 \mathrm{kcal} \mathrm{g}^{-1}$, lipid $=9.44 \mathrm{kcal} \mathrm{g}^{-1}$ and carbohydrate $=4.11 \mathrm{kcal} \mathrm{g}^{-1}$ (NRC, 1993).

Means of treatments presenting significant differences were compared by Dunnett's test at 5\% probability.

\section{RESULTS AND DISCUSSION}

Water quality parameters such as dissolved oxygen $\left(5.0 \pm 0.06 \mathrm{mg} \mathrm{L}^{-1}\right)$, temperature $\left(27.5 \pm 0.01^{\circ} \mathrm{C}\right), \mathrm{pH}$ (5.2 \pm 0.02$)$, electric conductivity $\left(21.8 \pm 0.39 \mu \mathrm{S} \mathrm{cm}^{-1}\right)$, total ammonia $\left(0.5 \pm 0.04 \mathrm{mg} \mathrm{L}^{-1}\right)$ and nitrite $\left(0.006 \pm 0.005 \mathrm{mg} \mathrm{L}^{-1}\right)$ did not present significant differences among treatments. The values observed were considered adequate for tropical fish culture (KUBITZA, 2003) and were according to those suggested for $\boldsymbol{C}$. macropomum (ARIDE, 1998).

The replacement of traditional commercial ingredients by alternative ingredients has been a frequent strategy in world fish farming. HANSEN et al. (2007) reported that, despite vegetal protein sources present inferior quality and lower digestibility compared to animal sources, these are cheaper option for feed formulation. Among these, the most studied are soybean, canola, sunflower and cotton bran. The inclusion of Amazon regional products in diets for tambaqui has also been investigated (SILVA et al., 2003; OLIVEIRA, 2005; PEREIRA JR., 2006).

After two months without mortality in all treatment, tambaqui juveniles fed diets containing different concentrations of Amazonian nut did not present significant differences in weight gain compared to the control animals (without Amazonian nut), at the same time interval (Figure 1). This is a relevant fact because the use of alternative ingredients frequently permits to reduce feed cost but with the consequent worsen animal performance. Thus, the preservation of performance and physiological status of the animals, even replacing part of the fish meal, are important indicators in the evaluation of alternative feeding.

These results corroborate with those obtained by LIMA (2009) for juvenile matrinxã (Brycon amazonicus) fed rations, that presents up to $45 \%$ of fish meal replaced by Amazonian nut bran, in which no difference in daily weight gain, specific growth rate and feed conversion ratio was found compared to control (without Amazonian nut). OLIVEIRA (2005) replaced $50 \%$ of commercial feed by fruits (catoré, jauari, embaúba and camu-camu) and seed (munguba) for juvenile tambaqui and did not find significant difference in weight gain and specific growth rate compared to fish fed with commercial diet. PEREIRA JR. (2006) did not find significant difference in weight gain, feed consumption, feed conversion ratio, protein efficiency ratio and specific growth rate in tambaqui fed diets with different leucena leaf meal concentration in replacement to fish meal.

On the other hand, BRASIL et al. (2007) emphasized the importance of physiological status of tambaqui fed with a higher leucena concentration (21\%) in diet, that presented hyperglycemia and anemia compared to other treatments, with the same performance, during the experiment. According to URBINATI \& CARNEIRO (2004), subnutrition caused by unbalanced diet is one of the most deleterious stressing conditions for biological homeostasis of the organism, contributing for the failure of cultivation.

Animal exposure to stressing conditions causes several physiological responses known as stress response, characterized by the activation of two components of the endocrine system: catecholamines and corticosteroids (BARTON, 2002). Secondary effects of these hormones, characterized by hyperglycemia, increase in total protein, hematological alterations, osmotic unbalance, among others, can indicate an important practice which helps the evaluation of fish health conditions. Tertiary responses affect negatively growth, disease resistance and reproductive success of animals. 


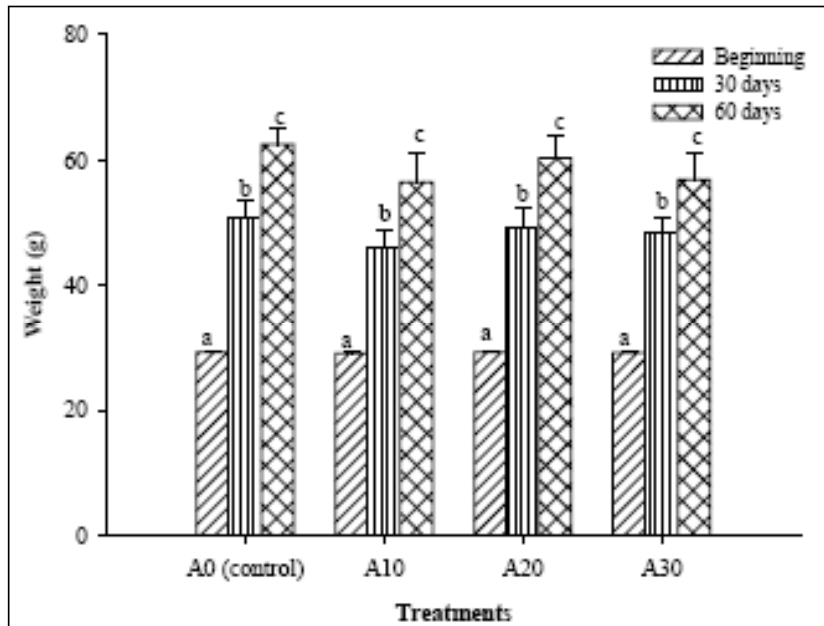

Figure 1 - Tambaqui, Colossoma macropomum, mean weight at the beginning, 30 and 60 days of feeding with: A0 (control), A10, A20 and A30 with 0, 10, 20 and 30\% Amazonian nut meal in the diet. Mean $\pm S D, n=60$. Different letters indicate statistical difference $(\mathrm{P}<0.05)$ in the treatment along the experimental period.

Analyses of hematological parameters have contributed to evaluate the animal health status (TAVARES-DIAS \& MORAES, 2004; AFFONSO et al., 2007). These parameters can indicate hemoconcentration or hemodilution. Hemoconcentration may be a strategy to increase oxygen transport capacity of blood under high energy demand in stressful situations (TRENZADO et al., 2006). However, stressing agents can affect iron absorption and stimulate malformation or hemolysis of erythrocytes, hemoglobin synthesis inhibition and the competition for the oxygen binding site can cause a hemodilution or anemia in fish, reducing the oxygen transport capacity (TAVARES-DIAS \& MORAES, 2004).

In the present study an evaluation of the animal hematological parameters was done and the results are presented in table $2 . \mathrm{Ht}, \mathrm{RBC},[\mathrm{Hb}], \mathrm{MCHC}$ and $\mathrm{MCV}$ values did not present significant differences among treatments after 60 days of experiment. Except for the MCV, which presented significant decrease in all treatments after 60 days, the other blood parameters did not present significant differences compared to basal levels. This reduction of MCV was not caused by diet because fish from control treatment also demonstrated this decrease. This can be a consequence of the increase tendency in erythrocyte number in the fish after 60 days.

The increase in blood glucose level is a characteristic response of fish exposed to acute or chronic stress factors (TRENZADO et al., 2006). In the present research, the results demonstrated that the plasmatic glucose concentration was not influenced by the increasing levels of Amazonian nut in feeding (Table 2). Similar results were obtained for plasmatic total protein concentration, an important indicator of animal physiological condition.

\section{CONCLUSION}

The results of the present study suggest that adding up to $30 \%$ of Amazonian nut to juvenile tambaqui feed do not compromise physiological homeostasis and water quality. Fish performance also supports this conclusion, considering that there was no difference among treatments compared to the control. Thus, Amazonian nut residue is a potential substitute for traditional ingredients in tambaqui feed, such as fish meal.

\section{ACKNOWLEDGEMENTS}

The author thanks to Conselho Nacional de Desenvolvimento Científico e Tecnológico ( $\mathrm{CNPq}$ ) for the

Table 2 - Hematocrit (Ht), red blood cell (RBC), hemoglobin (Hb), mean corpuscular hemoglobin concentration (MCHC), mean corpuscular volume (MCV), plasma glucose (Gl) and total plasma protein (TPP) of tambaqui juveniles fed different concentrations of Amazonian nut meal in the diet. A0 (control), A10, A20, A30 with 0, 10, 20 and 30\% Amazonian nut meal, respectively. Mean $\pm S D, n=18$.

\begin{tabular}{|c|c|c|c|c|c|c|c|c|}
\hline $\begin{array}{l}\text { Time } \\
\text { (days) }\end{array}$ & Treatment & $\begin{array}{l}\mathrm{Ht} \\
(\%)\end{array}$ & $\begin{array}{c}\mathrm{RBC} \\
\left(\times 10^{6} \mu \mathrm{L}^{-1}\right)\end{array}$ & $\begin{array}{c}\mathrm{Hb} \\
\left(\mathrm{mmol} \mathrm{L}{ }^{-1}\right)\end{array}$ & $\begin{array}{l}\mathrm{MCHC} \\
\left(\mathrm{g} \mathrm{dL}^{-1}\right)\end{array}$ & $\begin{array}{l}\text { MCV } \\
\text { (fL) }\end{array}$ & $\begin{array}{c}\text { Gl } \\
\left.(\mathrm{mmol} \mathrm{L})^{-1}\right)\end{array}$ & $\begin{array}{c}\text { TPP } \\
\left(\mathrm{g} \mathrm{L}^{-1}\right)\end{array}$ \\
\hline 0 & Basal & $30.2 \pm 4.7$ & $1.8 \pm 0.2$ & $5.8 \pm 1.4$ & $31.1 \pm 5.9$ & $170.9 \pm 4.8 \mathrm{a}$ & $2.6 \pm 1.0$ & $19.8 \pm 0.8$ \\
\hline \multirow{4}{*}{60} & $\mathrm{~A} 0$ & $31.3 \pm 2.5$ & $2.2 \pm 0.1$ & $6.3 \pm 0.3$ & $32.9 \pm 1.3$ & $139.4 \pm 4.5 b$ & $3.7 \pm 3.0$ & $17.1 \pm 1.5$ \\
\hline & $\mathrm{A} 10$ & $31.8 \pm 3.1$ & $2.3 \pm 0.2$ & $6.4 \pm 0.4$ & $34.1 \pm 0.4$ & $138.0 \pm 9.5 b$ & $4.7 \pm 1.3$ & $18.1 \pm 4.2$ \\
\hline & $\mathrm{A} 20$ & $30.8 \pm 3.4$ & $2.5 \pm 0.3$ & $6.5 \pm 0.5$ & $32.3 \pm 1.6$ & $133.2 \pm 3.5 b$ & $4.4 \pm 0.7$ & $18.4 \pm 3.3$ \\
\hline & $\mathrm{A} 30$ & $33.5 \pm 3.5$ & $2.3 \pm 0.3$ & $6.3 \pm 0.6$ & $31.5 \pm 2.5$ & $140.7 \pm 5.9 b$ & $4.9 \pm 1.0$ & $18.3 \pm 1.9$ \\
\hline
\end{tabular}

Different letters indicate statistical difference $(\mathrm{P}<0.05)$ among treatments and basal levels.

Ciência Rural, v.40, n.10, out, 2010. 
grant received and to $\mathrm{CNPq}$, Fundação de Amparo à Pesquisa do Estado do Amazonas and Instituto Nacional de Pesquisas da Amazônia (PPI -No. PRJ05.63)

\section{REFERENCES}

AFFONSO, E.G. et al. Effect of high levels of dietary vitamin $\mathrm{C}$ on the hematological blood responses of matrinxã. Comparative Biochemistry and Physiology, Part A, v.147, p.383-388, 2007. Available from: <http://dx.doi.org/10.1016/ j.cbpa.2007.01.004>. Accessed: Nov. 15, 2009. doi:10.1016/ j.cbpa.2007.01.004.

ANDRADE, J.I.A. et al. Influence of diets supplemented with vitamin $\mathrm{C}$ and $\mathrm{E}$ on pirarucu blood parameters. Comparative Biochemistry and Physiology, Part A, v.146, p.576-580, 2007. Available from: <http://dx.doi.org/10.1016/ j.cbpa.2006.03.017>. Accessed: Nov. 29, 2009. doi:10.1016/ j.cbpa.2006.03.017.

ARIDE, P.H.R. Efeito do pH nos parâmetros hematológicos e no ganho de peso de Colossoma macropomum (Cuvier, 1818). 1998. 52f. Dissertação (Mestrado em Biologia de Água Doce e Pesca Interior) - Instituto Nacional de Pesquisas da Amazônia/Universidade Federal do Amazonas. Manaus, AM.

BARTON, B.A. Stress in fishes: A diversity of responses with particular reference to changes in circulating corticosteroids. Integrative \& Comparative Biology, v.42, p.517-525, 2002.

BOYD, E.; TUCKER, C.S. Water quality and pond soil analyses for aquaculture. Auburn: Alburn University, 1992. $300 \mathrm{p}$.

BRASIL, E.M. et al. Parâmetros sanguíneos de tambaqui, alimentado com diferentes concentrações de leucena. In: CONGRESSO BRASILEIRO DE ENGENHARIA DE PESCA, 15., 2007, Manaus, AM. Anais... Manaus: Universidade Federal do Amazonas, 2007. V.1. 147p. p.104.

HANSEN, A.C. et al. Total replacement of fish meal with plant proteins in diets for Atlantic cod (Gadus morhua L.) I Effects on growth and protein retention. Aquaculture, v.272, p.599-611, 2007. Available from: <http://dx.doi.org/10.1016/ j.aquaculture.2007.08.034>. Accessed: Jan. 11, 2010. doi:10.1016/j.aquaculture.2007.08.034.

IBAMA (Instituto Brasileiro do Meio Ambiente e dos Recursos Naturais Renováveis). Estatística da Pesca 2007 Brasil: Grandes Regiões e Unidades da Federação. Brasília, DF, 2007. 113p.

KUBITZA, F. Qualidade da água no cultivo de peixes e camarões. Jundiaí: Acqua Imagem 2003. 229p.

LIMA, M.A.C. Farelo de soja e farelo de castanha da Amazônia substituindo parcialmente a proteína animal na dieta de juvenis de matrinxã: aspectos zootécnicos, fisiológicos e econômicos. 2009. 42f. Dissertação (Mestrado em Biologia de Água Doce e Pesca Interior) - Instituto Nacional de Pesquisas da Amazônia. Manaus, AM.
NRC (National Research Council). Nutrient requirements of fish. Washington, 1993. 114p.

OLIVEIRA, A.M. Aspectos fisiológicos e bioquímicos do tambaqui alimentados com dietas suplementadas por frutos e sementes de áreas alagáveis. 2005. $73 \mathrm{f}$. Dissertação (Mestrado em Biologia de Água Doce e Pesca Interior) - Instituto Nacional de Pesquisas da Amazônia. Manaus, AM.

ONO, E.A. Cultivar peixes na Amazônia: possibilidade ou utopia? Panorama da Aqüicultura, julho/agosto, p. 41-48, 2005.

PEREIRA JR., G. Farinha de folha de leucena como fonte de proteína para juvenis de tambaqui (Colossoma macropomum). 2006. 44f. Dissertação (Mestrado em Agricultura no Trópico Úmido) - Instituto Nacional de Pesquisas da Amazônia. Manaus, AM.

ROUBACH, R. et al. Aquaculture in Brazil. World Aquaculture, v.34, p.28-35, 2003.

SALZE, G. et al. Use of soy protein concentrate and novel ingredients in the total elimination of fish meal and fish oil in diets for juvenile cobia, Rachycentron canadum. Aquaculture, v.298, p.294-299, 2010. Available from: <http://dx.doi.org/ 10.1016/j.aquaculture-.2009.11.003>. Accessed: Mar. 02, 2010. doi:10.1016/j.aquaculture.2009.11.003.

SILVA, J.A.M. et al. Frutos e sementes consumidos pelo tambaqui, Colossoma macrompum (Cuvier, 1818) incorporados em rações: digestibilidade e velocidade de trânsito pelo trato gastrointestinal. Revista Brasileira de Zootecnia, v.32, n.6, p.1815-1824, 2003.

SOUZA, M.L.; MENEZES, H.C. Processamento de amêndoa e torta de castanha-do-Brasil e farinha de mandioca: parâmetro de qualidade. Ciência e Tecnologia de Alimentos, v.24, n.1, p.120-128, 2004

TACON, A.G.J. et al. Use of fishery resources as feed inputs to aquaculture development: Trends and policy implications. Rome: FAO Fisheries, 2006. 114p. (Circular n. 1018).

TAVARES-DIAS, M.; MORAES, F.R. Hematologia de peixes teleósteos. Ribeirão Preto: São Paulo, 2004. 144p.

TRENZADO, C.E. et al. Physiological effects of crowding in rainbow trout selected for low and high stress responsiveness. Aquaculture, v.258, p.583-593, 2006. Available from: <http:/ /dx.doi.org/10.1016/j.aquaculture.2006.03.045>. Accessed: Jan. 12, 2010. doi:10.1016/j.aquaculture.2006.03.045.

URBINATI, E.C.; CARNEIRO, P.C.F. Práticas de manejo e estresse dos peixes em piscicultura. In: CYRINO, J.E.P. et al. Tópicos especiais em piscicultura de água doce tropical intensiva. São Paulo: Sociedade Brasileira de Aqüicultura e Biologia Aquática, 2004. Cap.6, p.171-193.

VERDOUW, $\mathrm{H}$. et al. Ammonia determination based on indophenol formation with sodium silicylate. Water Research, v.12, p.397-402, 1978. 